\title{
FIBROSITIS AND INFECTION
}

\author{
By DOUGLAS H. COLLINS \\ Definition of Fibrositis
}

IT is traditional and etymologically correct to define fibrositis as an inflammation of fibrous tissue; but this is an inadequate definition of the clinical state to which the name applies. It is not yet established that inflammation is the only process, or fibrous tissue the only tissue, concerned in the pathogenesis of the disease. Fibrositis must therefore be defined afresh in clinical terms. It may then be clear that the subsequent discussion concerns a familiar clinical condition without assuming any uniform and established pathology for it.

Fibrositis, then, is an acute or chronic painful state of the subcutaneous tissues, muscles, fasciæ, ligaments or tendons, arising independently of gross anatomical disease from which pain might be referred. The pain of fibrositis has the more or less uniform quality which Lewis ${ }^{1}$ attributes to all pains arising from deep somatic structures, irrespective of the nature of their stimulus. It is felt both locally at certain tender points and referred according to segmental distribution (Kellgren $\left.{ }^{2}\right)$. The painful state of fibrositis is sometimes, but not invariably, associated with localised indurations or nodules palpable through the skin, and these frequently coincide with points of maximum tenderness. These so-called fibrositic nodules can sometimes be dispersed by massage and, if they are the focal points from which the pain originates, relief and even permanent cure of the symptoms can often be obtained by infiltrating them with local anæsthetic.

\section{General Atiology of Fibrositis}

Fibrositis is usually classed as a rheumatic disease, and the numerous and varied ætiological factors attributed to other rheumatic diseases have also been assigned to it-e.g., climate, occupation, trauma, endocrine disturbances, the "rheumatic diathesis", psychoneurotic states, and infection. The last only will be considered in detail here. There are good grounds for 
believing that a high proportion of cases diagnosed by practitioners as fibrositis have an obviously non-infective ætiology. Amongst these may be mentioned-(a) the painful states caused by abnormal strains on ligaments and tendons, including the late result of acute traumatic sprains and the painful conditions of muscles caused by unwonted athletic exercise, fatigue, or faulty posture; (b) the painful states of the subcutaneous tissues in endocrine disease, seen in an exaggerated form in Dercum's disease; and (c) the varieties of muscular cramp resulting from local vascular disturbances. The clinical differentiation of these variously caused somatic painful states is often difficult. The doctor must, however, be aware of their variety and view the condition of fibrositis eclectically, not as a specific disease entity but as a common manifestation of a diversity of underlying conditions.

A precise ætiology cannot be ascribed to all clinical cases of fibrositis. Many cases are attributed to "infection," by which is generally understood the absorption of bacteria or bacterial toxic products from foci of bacterial growth in teeth, tonsils, gut, or elsewhere. Some practitioners recognise a state of fibrositis to co-exist with the more clearly defined diseases of rheumatic fever and rheumatoid arthritis. This should be regarded as a secondary fibrositis and a part of the major disease. It is not an argument in favour of fibrositis in general being one of many manifestations of a single comprehensive specific rheumatism. The cases of fibrositis which never show any signs of articular or cardiac disease are far more numerous. There is, however, a form of fibrositis which principally affects the tissues in the region of the joint, but it appears that this can be distinguished from actual arthritis $\left(\right.$ Slocumb $\left.^{3}\right)$.

The conditions known as "muscular rheumatism" and "non-articular rheumatism" are included within the term "fibrositis" in my discussion. I shall make no special mention of neuritis. The neurologists have sufficiently defined certain specific forms of interstitial neuritis, and recent information about lesions of the intervertebral discs and of the ligamentum flavum is removing more and more cases of sciatica from the fibrositic category.

We have already seen that there are numerous cases which, for lack of a better word, can be diagnosed as fibrositis and which we now know to have a non-infective basis. The object of my discussion now is to consider whether infective causes can be 
definitely attributed to any of the remaining cases. This I propose to do by examining the evidence under three heads: (1) morbid anatomy, (2) clinical pathology, and (3) analogy with known infective states.

1. Morbid Anatomy.-Our information on this subject is meagre. The disease is not fatal, and it is not recognisable in the post-mortem room. Biopsy material alone is available, but patients are reluctant to allow biopsies when their physicians cannot promise that the procedure will be beneficial.

The observations of Stockman ${ }^{4}$ have been quoted over and over again in books and papers and have been generally accepted without criticism. Stockman excised and examined a number of fibrositic indurations. He described the microscopical changes as inflammatory hyperplasia of connective tissue which contained fibroblasts, a greater or lesser sero-fibrinous exudation, but no leucocytes. All cultures were sterile. "In view of our present knowledge," Stockman wrote, "it seems at least likely that these local fibroses are due to small colonies of microbes invading the tissues and causing a reaction which comparatively rapidly destroys the invaders. The organisms are non-pyogenic ... there is no softening of the tissues and no pus formation, bute instead they leave behind a small patch of inflamed fibrouso tissue which persists and spreads." He went on to state that the exacerbations and relapses of the condition suggest a chronic general infection by an organism of attenuated virulence with "irritation from its toxin". But he also stated that the frequent exacerbations and tendency to spread might be due to "irritating causes other than microbic, such as constantly recurring exposure to cold and damp ". Stockman's material is almost unique and consequently of great importance. I have examined some of it myself, but I am convinced that no deductions whatever concerning the causation of the fibrositic nodule can be drawn. The illustrations in Stockman's book are not impressive. Five of them show scarcely more variation in fibrous tissue structure than can be encountered normally in different situations in the body. The sixth depicts a fibrosed and re-canaliculised thrombotic vessel. In my view, Stockman's most important findings were negative ones-i.e., the absence of leucocytic infiltration of the fibrositic nodules and the sterility of the cultures prepared from them.

In a later chapter Stockman considered panniculitis-a 
painful nodular condition of the subcutaneous mesenchymal tissues which most physicians regard as a fibrositis. Here again the histological changes so nearly resembled normal anatomical variations that no important deductions as to ætiology can be made from them. Stockman noted that the painful subcutaneous nodules often resembled encapsulated lipomata; but he distinguished between the rheumatic condition and adiposis dolorosa resulting from disease of the pituitary gland. To me it seems quite possible, in view of the age grouping and general nutritional state of these patients, that minor endocrine disturbances may play a part in the so-called rheumatic panniculitis.

My own experience in the histology of biopsy tissue from cases of fibrositis may be recorded here. It is a limited and somewhat unsatisfactory experience, but so little is known of the subject that any information at all may be of value. I have examined upwards of fifty subcutaneous nodules from various forms of rheumatic disease. Of these, seven relate to the subject under discussion. They were kindly removed for me by Mr. T. V. Pearce, surgeon to the Harrogate Royal Bath Hospital and the Harrogate General Infirmary, and all except those in Cases 6 and 7 had been diagnosed by experienced physicians as "typical fibrositic nodules ".

CASE 1.-Female aged forty-seven. Chronic pain in the small of the back and right buttock following hysterectomy four years previously. Behind the right sacro-iliac joint " a massive fibrositis" was palpable. One large and a few small nodules could be rolled under the examiner's finger. They were tender. Their removal was followed by an improvement in the local symptoms.

Pathology.-The tissue consisted of irregular lobulated fatty masses enclosed in a fibrous capsule and lying in the general subcutaneous fat. Microscopically they resembled simple lipomata and showed no evidence of inflammatory change.

Case 2.-Female aged fifty. Pain in left buttock and down left leg for four years. "Large fibrositic masses in the lumbar and gluteal muscles or subcutaneous tissue." No X-ray abnormalities. A nodule was removed from the left buttock. The pain down the leg was not relieved.

Pathology.-Adipose tissue with some fibrous encapsulation. Probably a simple lipoma. The tissue is relatively avascular. No inflammatory changes.

CASE 3.-Female aged twenty-five. "Fibrositic nodules" from the posterior sacro-iliac region.

Pathology.-Lobulated adipose tissue with no inflammatory changes.

CASE 4.-Female aged thirty. Diagnosed as fibrositis by an experienced physician. A "fibrositic nodule" was removed from amongst the flexor muscles of the left forearm. 
Pathology.-A firm white nodule measuring about $1 \mathrm{~cm}$. in diameter, which proved on microscopical examination to be a typical neurofibroma. The case was thereupon diagnosed correctly as von Recklinghausen's disease.

CASE 5.-Female aged forty-two. Rheumatoid arthritis affecting many joints for five years. General condition much improved and sedimentation rate returned to normal. Numerous tender and painful subcutaneous nodules gave rise to the diagnosis of fibrositis secondary to the arthritis. A small nodule was removed from the plantar fascia beneath each heel.

Pathology.-Tough fibrous nodules which on section showed the typical structure of the subcutaneous nodules of rheumatoid arthritis, which I have described in detail elsewhere. ${ }^{5}$ It would seem misleading to consider this fibrositic state as merely secondary to the arthritis. It is an integral part of the major disease.

CASE 6.-Female aged twenty-five, an ardent and persistent worshipper. A small hard and painful nodule overlay the left patella tendon and interfered with kneeling. The nodule when removed measured $1 \times 1 \times 1.5 \mathrm{~cm}$.

Pathology.-The section showed an irregular mass of fibrous tissue lying in fat. The tissue was considerably vascular save in the central degenerated area. Many of the bloodvessels were cuffed by lymphocytes, and small lymphorrhages were also seen elsewhere. There were no polymorphs or plasma cells. Some of the collagen showed hyaline change and towards the centre of the tissue there were areas of loosely reticulated "fibrinoid" or " mucoid" degeneration of the fibrous tissue. There was no intense fibroblastic reaction around these areas.

This patient's nodule was never diagnosed as fibrositic. It was thought to be traumatic in origin, and the microscopical appearances are consisten with this view. The nodule, however, showed many of the structuraf changes which have been repeatedly quoted as being characteristic of fibrositis. The case is mentioned as a warning against the careless assumption of infection as the sole cause of such changes.

CASE 7.-Male aged eighteen, a student who for six months complained of a snapping middle finger. A small nodule, less than $1 \mathrm{~cm}$. in diameter, was enucleated from the fibres of the deep flexor tendon. It gave rise to the symptoms by catching as it slipped through the fork of the flexor digitorum sublimis tendon.

Pathology.-The bulk of the nodule was myxomatous fibrous tissue irregularly spattered with fibroblasts and thin-walled capillaries. Infiltrating leucocytes were very rare. Expert histologists to whom I showed the sections failed to agree as to whether the tissue was granulomatous or neoplastic. This condition is unlikely to be called rheumatic, though it might be thought fibrositic and possibly related to the tendinous fibrositis of which Dupuytren's contracture may be a type. An infective ætiology was unproved in this case. The case further shows how difficult it is to decide upon the ætiology from the pathological appearances of even so well localised a lesion of fibrous tissue.

Of these seven cases, the first three examinations confirm Stockman's findings in panniculitis. They do not help us to come to any decision regarding ætiology. The complete absence 
of inflammatory changes does not suggest an infective origin. The degree of fibrosis seen around the fatty masses was no more than that which occurs around simple lipomata. It did not amount to anything suggesting post-inflammatory cicatrisation. Some authors have described interstitial changes in the nervetwigs in these nodules and thereby explain their painfulness. I was unable to satisfy myself on this point.

Case 4 was a straightforward and understandable misdiagnosis. It is described merely to show how wary the physician must be to exclude certain already well-defined conditions from the fibrositic category. Case 5 is intended to show that the " secondary" fibrositis accompanying rheumatoid arthritis may be an integral part of the major disease. Case 6 demonstrates that purely traumatic causes may explain some of the histological changes of fibrous tissue which have been thought essentially infective inflammations. Case 7 is a local condition of tendinous fibrous tissue of unknown ætiology.

The 1933 B.M.A. Committee on arthritis and allied conditions ${ }^{6}$ describes the fibrositic nodule as "formed by blocking of the lymphatics followed by a localised leucocytic infiltration, and this, in turn, by fibrosis and scar formation ". The description is not very enlightening. It is hard to understand and it might apply almost as well to a surgical cicatrix. The Committee goes on to say, however, that " there is no record of a recovery of micro-organisms from fibrositic nodules".

Many writers have regarded the painful nodules as muscular indurations. The small acutely tender lumps that can be felt within a few hours of the onset of some fibrositic pains do, indeed, suggest local spastic contractions of muscle, and these, moreover, can often be dispelled quickly by firm massage. Gräff $^{7}$ could find no histological changes in any biopsy material from cases of muscular rheumatism, apart from the specific Aschoff nodes, which he was able to find in voluntary as well as in cardiac muscle in acute rheumatic fever.

Fischer ${ }^{8}$ describes as muscular rheumatism the same condition which we include under the heading of fibrositis, and considers it to be most frequently secondary to diseases of the joints and of the vertebral column. This he calls secondary muscular rheumatism. Primary muscular rheumatism Fischer divides into myositis (inflammatory) and myalgia (non-inflammatory). The causes he gives for inflammatory myositis are all specific infections 
capable of manifesting themselves in other ways than subjectively felt pains-e.g., septicæmia, trichiniasis, gonorrhœa, and rheumatic fever. Non-inflammatory myalgia he attributes to hypothetical changes in the physico-chemical state of the muscles, and these present no morbid anatomical features.

A great difficulty in assessing the results of pathological examinations is the fact that the tissues which are affected in fibrositis are not highly differentiated and therefore their modes of reaction to various noxious agents are limited in type. It seems unlikely, on this ground, that further examinations of the morbid anatomy of the fibrositic lesions will add much to our knowledge of their cause. It is for this reason, too, that I regard the experimental production of lesions which might bear some resemblance to those of fibrositis as not decisive. Gordon ${ }^{9}$, by infecting rabbits with an attenuated variola virus, alone and in combination with hæmolytic streptococci, reproduced lesions of the periarticular tissues which he correctly termed "fibrositic", and sought to liken them to the lesions of human rheumatic fibrositis. The lesions that resulted from these experiments seem to me to be more clearly inflammatory than any yet reported as occurring in human fibrositis. This work of Gordon's is of great value in showing the synergic effects of a virus with streptococci and the manner in which the streptococci disappeared from the lesions when combined with the virus. The almost insuperable difficulty in experimental work directed towards the elucidation of fibrositis is the fact that in man fibrositis is essentially a subjective symptom which may or may not be associated with objective signs. The morbid anatomy of the condition in man remains so vague that its comparison with lesions produced experimentally in animals can never be free from doubt: Thus Stockman, to whom Gordon referred his sections, felt bound to say that though the rabbit lesions were " similar to those of rheumatic fibrositis in man " similar changes could be produced by other agencies-e.g., trauma.

Some information might be gained from a comparison of common fibrositis with gonorrhoeal fibrositis, but I have been unable to discover any details of the morbid anatomy of the latter beyond the bald statement in a textbook of medicine ${ }^{10}$ with reference to the painful heel of gonorrhœa that "organisms have been found in this situation".

Studies in morbid anatomy seem to me to prove that frank 
bacterial infection plays no part in ordinary fibrositis. Whether the lesions, such as they are, result from the action of bacterial toxins remains speculative.

2. Clinical Pathology.-The 1933 B.M.A. Committee on arthritis' quotes "septic foci, particularly in connexion with the teeth, tonsils, gall-bladder, and prostate", as some of the causes of fibrositis. This view was doubtless formulated as a result of the impression common among clinicians that focal sepsis bears an ætiological relationship to fibrositis. The view is not very well supported by the available statistical evidence, but it remains widely held by numerous physicians with a wide experience of the disease, and the fact that it is so held constitutes a powerful argument for its validity. The Ministry of Health 1924 Report11 considered the incidence in the insured population of muscular rheumatism, lumbago, and sciatica. None of these conditions was significantly associated with tonsillar sepsis. Dental sepsis, on the other hand, was found to be very frequent amongst sufferers from these diseases, but, as it was also frequent amongst the population at risk but unaffected by rheumatism, it could not be regarded as of proved ætiological significance. A strong claim to this was, however, made in the report. But there was also a correlation between the frequency of dental sepsis and increasing age. Lumbago and sciatica, which in the light of more recent knowledge appear to owe more to mechanical than to infective causes, were also found in this survey to be associated with dental sepsis as frequently as was muscular rheumatism. Last year Vaizey and Clark-Kennedy ${ }^{12}$ published a careful review of the relationship between dental sepsis and conditions of chronic ill-health, including rheumatism. They concluded that all the evidence of a causal relationship between dental sepsis and anæmia, dyspepsia, and rheumatism was equivocal and that serious criticism could be levelled against the bacteriological, statistical, and therapeutic data which have so far been produced to support such a causal relationship.

Laboratory examinations of the blood in fibrositis furnish no proof of the condition being infective. Secondary anæmia is uncommon. ${ }^{13}$ The sedimentation rate is generally normal. There is no leucocytosis nor any marked shift to the left of the neutrophil nuclear count. Levinthal ${ }^{14}$ found that agglutination and absorption tests with a group A hæmolytic streptococcus were negative in 73 per cent. of sera from cases of fibrositis, whereas 
they were positive in 72 per cent. of cases of rheumatoid arthritis.

Sufferers from fibrositis may show signs of fatigue from persistent pain, but they seldom appear toxic or lose weight. Their generally healthy aspect is often in marked contrast to their miserable story.

No one who has seen many cases of fibrositis can deny that occasionally successful eradication of a septic focus is followed by relief of symptoms or that a painful fibrositic state sometimes follows the development of a focal infection. Focal infections which appear to bear a causal relation with fibrositis seem to me to fall into two classes. Examples of each will emphasise the necessity for distinguishing between them.

The first example is that of a young man who develops tonsillitis and continues his work for a day or two until waking up one morning he finds himself almost unable to get out of bed on account of severe pains in the back and limbs. The doctor is called and diagnoses acute muscular rheumatism or fibrositis and prescribes aspirin and gargles. The aspirin mitigates the pain. The tonsillitis subsides in its own good time. Severe fibrositic pain persists perhaps for several days, but as the sore throat gets better so does the fibrositis and the patient ultimately recovers completely. The doctor naturally and, I believe, quite correctly links the tonsillitis to the fibrositis, and he may later advise tonsillectomy " to prevent a recurrence ". In such a case the sore throat has been a hæmolytic streptococcal infection, and the acute fibrositis a manifestation either of a transient septicæmia or of an acute bacterial toxæmia and can be compared with the acute painful states occurring in other septicæmias. Tonsillectomy will prevent a recurrence only if, by this measure, the patient escapes a future streptococcal angina. It does not follow from this example of an acute fibrositis clearly caused by infection that all other fibrositis is so caused.

The second example of focal infection apparently related to fibrositis is the case of an elderly multiparous woman who for years has suffered from lumbago and a vaginal discharge. She is found to have a chronic cervicitis, and this is appropriately treated. As the focal infection is cured the lumbago disappears. The case makes an impression on the physician's mind of fibrositis relieved by treatment of a septic focus. The truth is that this lumbago is not fibrositis; it is referred pain. 
It was discovered some years ago that local anæsthetic injected into and around a sprained ligament not only relieved pain but also prevented reactionary oedema and promoted recovery of function. Leriche, ${ }^{15}$ the pioneer in this field, believed that the local anæsthetic, by its effect on the sympathetic nerves, arrested inflammatory reaction to injury. Local anæsthetic can relieve and often permanently cure the symptoms of fibrositis if the right points of maximum tenderness are injected. The fact seems to indicate that no bacterial irritant persists in these tissues. Nor is it likely that the injection of small amounts of anæsthetic solution into one or two areas of subcutaneous tissue prevents all future manifestations of a condition caused by the continual absorption of "toxins" from a septic focus. The success of this form of treatment in so many cases of fibrositis strikes me as a strong argument against the focal infection theory. It may also be noted that some formerly ardent advocates of focal infection and vaccine therapy are to-day using procaine injections extensively in their treatment of fibrositis.

3. Analogy with Painful States in Known Infections.-Pain in the muscles; joints, and fasciæ frequently occurs in the early stages of many acute febrile diseases-e.g., typhoid fever, cerebrospinal fever, influenza, scarlatina, relapsing fever, leptospirosis, smallpox, and typhus. Such pain may last through the whole course of other diseases-e.g., brucellosis, trench fever, and dengue. The somatic pains, in the bacterial and protozoal infections, are contemporary with the septicæmic phase of the disease. This is possibly also the case in the rickettsial and virus diseases. The acute fibrositis in streptococcal angina may be compared with these examples. Generalised skeletal pains seem to be a frequent concomitant of septicæmia without distinction as to the invading micro-organism.

There is an acute febrile disease, not common in the British Isles, the major symptom of which is muscular and tendinous pain. Varieties of it have been named acute epidemic myalgia, "the devil's grip," or Bornholm disease. Its precise cause is unknown. It is communicable. Recovery is complete. It seems to bear no relation to common fibrositis.

Non-articular skeletal pains are now a well recognised symptom of acute rheumatism (rheumatic fever). Anatomical lesions resembling the Aschoff nodes of the myocardium have been found in the voluntary muscles by some (Gräff ${ }^{7}$ ), but others believe 
that the toxins either of a streptococcus or of an unidentified specific virus cause these pains. Healey ${ }^{16}$ noted that transient joint pains occurred during active immunisation with scarlet fever streptococcus toxin. A high proportion of the persons who developed these pains had a history of previous joint pains suggestive of rheumatic infection. The sensitivity of rheumatic fever subjects to sterile streptococcal products has also been shown by many others (e.g., Green ${ }^{17}$ ). The muscular pains of acute rheumatism are usually excluded from the category of fibrositis. The average patient with fibrositis shows no evidence of previous specific rheumatic infection, and it seems wiser to consider the two diseases as being entirely distinct.

Pyæmia, glanders, trichiniasis, and dermato-myositis cause focal inflammatory lesions of fibrous tissue and muscle. Histologically the lesions are quite different from those described in fibrositis.

From this short review it will be seen that painful states of muscle and connective tissue may result from bacterial septicæmia or toxæmia, and focal anatomical lesions from pyæmia and certain specific infections. But the general features of these diseases are so unlike those of common fibrositis that the analogy doeso not force the conclusion that the latter condition is also necessarilyo infective in origin.

SUMmary
The term fibrositis covers in common usage the ætiologically undefined conditions named myositis, myalgia, non-articular rheumatism, panniculitis, and periarthritis.

Fibrositis is a common clinical condition of vague pathology. It should be defined in clinical not in pathological terms. This I have attempted to do (p. 114).

A high proportion of cases of fibrositis have an obviously non-infective ætiology.

Fibrositis occurring in the course of rheumatic fever and rheumatoid arthritis has, on occasion, been proved to be associated with nodules in subcutaneous tissue or voluntary muscles characteristic of the major disease. No similar lesions have been described in fibrositis arising independently of these diseases. There is no reason, therefore, to regard all cases of fibrositis as being manifestations of a specific rheumatic infection.

The known morbid anatomy of fibrositis has been critically 
discussed and some new examinations of biopsy tissue have been recorded. Evidence of inflammation caused by infection in the fibrositic nodule is very slender. Leucocytic infiltration is generally absent. Cultures are always sterile. Reactions of connective tissues to various noxious agents are limited in type. No decision regarding the ætiology of the fibrositic nodule can be made on the available pathological data.

Animal experiments are unlikely to elucidate the causes of human fibrositis, which is essentially a subjective phenomenon. It is also often difficult to distinguish between fibrous tissue lesions arising from different causes.

Laboratory examinations of the blood in fibrositis lend no support to the view that the condition is generally infective.

Only in rare instances can it be considered proved that focal infection is a cause of fibrositis.

Acute focal infection, especially hæmolytic streptococcal tonsillitis, may cause acute fibrositis. Body pains, resembling acute fibrositis, also occur during the septicæmic or invasion phases of many specific infective fevers.

Chronic focal infection, particularly of the pelvic organs, may give rise to chronic referred pain. Disappearance of this pain on treatment of the deep-seated infection may be misinterpreted as cure of fibrositis by removal of a septic focus.

\section{General Conclusion}

Acute septicæmic and toxæmic infections can cause acute fibrositis. Chronic infections of viscera can cause chronic referred pain. Rheumatic fever and rheumatoid arthritis, both probably infective diseases, can cause specific varieties of fibrositis. Painful nodular lesions of muscular and connective tissue develop in certain specific infections-e.g., glanders and trichiniasis. Gonorrhœal fibrositis is recognised. Apart from these instances there is no sound evidence that fibrositis originates in infection. Other ætiological factors are at least as likely to be concerned in the majority of cases of fibrositis.

\section{REFERENCES}

1. Lewis, T.: Brit. Med. Journ., 1938, i. 321.

2. Kellgren, J. H.: Clinical Science, 1939, iv. 35.

3. Slocumb, C. H. : Journ. Lab. and Clin. Med., 1936, xxii. 56. 
4. Stockman, R.: "Rheumatism and Arthritis." Edinburgh, 1920.

5. Collins, D. H.: Journ. Path. and Bact., 1937, xlv. 97.

6. B.M.A. Committee on Arthritis and Allied Conditions: Brit. Med. Journ., 1933, i. 1033.

7. GRÄFF, S.: "Rheumatismus und rheumatische Erkrankungen." Berlin, 1936.

8. Fischer, A.: "Rheumatismus und Grenzgebiete." Berlin, 1933.

9. Gordon, M. H.: This journal, 1939, i. 5 .

10. "A Textbook of the Practice of Medicine," edited F. W. Price, 1930. Third Edition, p. 1242.

11. Ministry of Health Reports on Public Health and Medical Subjects: No. 23, 1924- "The Incidence of Rheumatic Diseases."

12. Vaizey, J. M., and Clark-Kennedy, A. E.: Brit. Med. Journ., 1939, i. 1269 .

13. Collins, D. H.: Lancet, 1935, ii. 548.

14. Levinthal, W.: Proc. International Congress on Rheumatism, 1938, 345.

15. Leriche, R.: Presse Médicale, 1938, xlvi. 1625.

16. Healey, C. E.: Journ. Amer. Med. Assoc., 1937, cviii. 628.

17. Green, C. A.: Journ. Path. and Bact., 1938, xlvii. 337. 